\title{
The World Journal of Surgery Welcomes Two New Associate Editors, Stephen Wigmore and Walter Marti
}

\author{
John Hunter
}

Published online: 31 December 2008

(c) Société Internationale de Chirurgie 2008

\section{Stephen Wigmore}

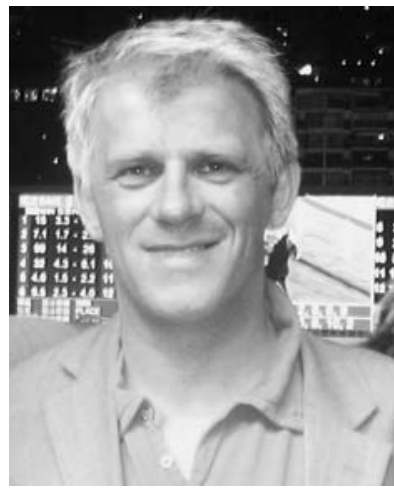

The World Journal of Surgery is pleased to welcome a new associate editor to our editorial board. Stephen Wigmore, who is Professor of Transplantation Surgery in Edinburgh, Scotland, will replace Professor $\mathrm{O}$. James Garden as one of two Associate Editors with an interest in HPB surgery and liver transplantation. We are extremely grateful to Professor Garden for his service to the journal over the past 4 years and are sad to lose him to HPB Surgery, where he will assume the role of Editor in Chief.

Professor Wigmore graduated from King's College School of Medicine and Dentistry, London (BSc). After two more years in London he moved to Edinburgh to undertake his basic and higher surgical training with Professor Sir David Carter and Professor James Garden. He was appointed Professor of Transplantation Surgery at the University of Birmingham and Liver Unit, Queen Elizabeth Medical Centre in 2005 and returned to Edinburgh only recently.

His clinical interests lie in liver transplantation and hepatobiliary surgery, and his principal research focus is on the cell and molecular biology of organ preconditioning

\section{J. Hunter $(\square)$}

Department of Surgery, School of Medicine, Oregon Health

Sciences University, 3181 SW Sam Jackson Park Road,

Portland, OR 97239, USA

e-mail: hunterj@ohsu.edu and stress protein expression. Professor Wigmore also sits on the editorial board of Transplantation, reviews grants for national and international agencies, and is the Specialty Advisor on Organ Donation and Transplantation to the Scottish government.

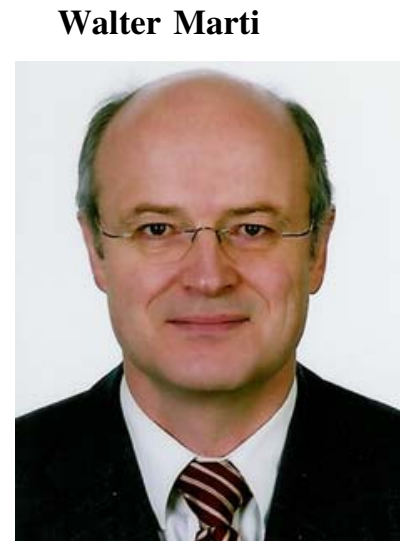

I am pleased to welcome Walter Marti, M.D. to our team of associate editors. Professor Marti is the Vice Chairman of Surgery at the University Hospital in Basel, Switzerland. He trained in Basel and Zurich, and had made surgical oncology his clinical and research focus. Recently, he received an executive MBA from St. Gallen. Most of Professor Marti's publications and research funding focus on colorectal cancer metastases and breast cancer. He has been funded by the Swiss Government to investigate $\mathrm{T}$ cell response to melanoma and single cell dissemination of colorectal cancer. His clinical interests include breast cancer, colon cancer, and a wide variety of surgical oncology.

As an editor of the World Journal of Surgery over the past 4 years, Dr. Marti has distinguished himself as a superb and timely critic of cancer manuscripts. His expertise in a wide variety of cancers and cancer-related topics is a great asset for the WJS. We understand that our journal is only as good as the surgeons who volunteer their time to review the $1000+$ original scientific manuscripts submitted to the WJS. Walter Marti is one of the best. Many thanks, Professor. 